\title{
MODIFIED VAC DRESSING IN STERNAL WOUND INFECTION MANAGEMENT. CHEAP AND FEASIBLE TECHNIQUE IN DEVELOPING COUNTRY
}

\author{
Yan Efrata Sembiring \\ Division of Thoracic, Cardiac \& Vascular Surgery, Department of Surgery, \\ Faculty of Medicine, Universitas Airlangga, Dr. Soetomo General Hospital, Surabaya, Indonesia
}

\begin{abstract}
ABSTRAK
Infeksi luka sternum adalah kasus yang jarang, namun dapat menimbulkan komplikasi yang serius pada pembedahan jantung. Pada kurun waktu terakhir, beberapa metode pengobatan telah diterapkan, dimana sistem VAC (vaccum assisted closure) menunjukkan hasil yang paling menjajikan. Namun metode pengobatan dengan sistem VAC ini membutuhkan biaya yang mahal dan perlengkapan yang banyak serta kebutuhan listrik yang terus-menerus. Modifikasi sistem VAC ini yang digunakan untuk mengobati infeksi luka sternum didapatkan tehnik yang murah dan layak untuk digunakan di negara yang berkembang. Tehnik ini dapat digunakan sebagai alternatif dari sistem VAC dressing yang asli dan menunjukan fungsi dalam memberikan tekanan negatif yang cukup untuk luka. (FMI 2016;52:225-230)
\end{abstract}

Kata kunci: infeksi luka sternum, modifikasi VAC dressing

\begin{abstract}
Sternal wound infection is a rare but serious complication of cardiac surgery leading to prolonged hospital stay and higher mortality. In the last decades several treatment modalities have been described, of which vacuum-assisted closure (VAC) shows the most promising results. However, the VAC therapy system is expensive, requires extensive amounts of product and needs a power source at all times. Modified VAC dressing to treat sternal wound infection is cheap and feasible technique to use in develop country. This technique can be use as an alternative to the original vacuum-assisted closure and hadshown to serve its function in providing adequatevacuum pressure for wounds. (FMI 2016;52:225-230)
\end{abstract}

Keywords: sternal wound infection, modified VAC dressing

Correspondence: Yan Efrata Sembiring, D Division of Thoracic, Cardiac \& Vascular Surgery, Department of Surgery, Faculty of Medicine, Universitas Airlangga, Dr. Soetomo General Hospital, Surabaya, Indonesia

\section{INRODUCTION}

Deep sternal wound infections (DSWI), namely mediastinitis and osteomyelitis, are a serious complication occurring in $1 \%$ to $5 \%$ of patients after cardiothoracic operations in individual studies. Post-sternotomy mediastinitis is debilitating and often fatal, with high mortality rates of up to $30 \%$ (Roemer et al 2011). Intravenous antibiotics and several surgical techniques had been used in the past for their treatment; however, they have been associated with increased short and long-term mortality (Fleck et al 2006, Bovill et al 2008). It also implies a prolonged hospital stay and increased nursing care, it is also considered to have a substantial impact on the health care system economy (Christian et al 2013).

Before 1980, sternal debridement, mediastinal irrigation, and rewiring was the preferred approach, which was followed by a hype for coverage with autologous (omental or muscle) flaps. A decade ago, plate fixation came into play but remained poorly accepted. Recently, negative pressure wound therapy, also termed vacuum therapy, was introduced as another treatment modality, especially in the case of deep sternal wound infection, and has gained widespread acceptance within a short period of time for its simplicity (Leopold \& Christof 2013).

\section{Sternal Wound Infection}

Median sternotomy was reintroduced by Julian in 1957 after its initial description by Milton in 1897 and become the most common approach for cardiac surgery. Despite the use of sterile technique, perioperative antibiotics and careful wound management, surgical site infections resulting in mediastinitis still become a serious problem (Roemer et al 2011). Various risk factors have been related to the development of deep sternal wound complications.

Deep sternal complications involve not only skin and subcutaneous tissue but may also affect the bone. Infection of the sternal wires can also be present. With 
regard to the specific surgical treatment, deep sternal complication can be discriminate as following pathologies: noninfected sternal instability, deep sternal wound infection without sternal instability, and deep sternal wound infection with sternal instability (Leopold \& Christof 2013).

Table 1. Risk factors for deep sternal wound complication (Singh et al 2011, Michael et al 2010)

\begin{tabular}{lll}
\hline \multicolumn{1}{c}{ Pre-Op } & \multicolumn{1}{c}{ Intra-Op } & \multicolumn{1}{c}{ Post-Op } \\
\hline BMI/Obesity & Longer operation time & IABP support \\
Coronary artery disease & Number of grafts & ICU stay > 2days \\
Diabetes insulin dependent & Redo surgery & More blood loss (repeat transfusion) \\
Low ejection fraction & $\begin{array}{l}\text { Use of BIMA (bilateral internal } \\
\text { mammary artery) }\end{array}$ & Re-exploration \\
Male gender & $\begin{array}{l}\text { Excessive use of bone } \\
\text { wax/diathermy }\end{array}$ & Prolonged ventilation \\
Mechanical ventilation & & Renal failure \\
NYHA class & & \\
Peripheral arterial disease & & \\
COPD & & \\
Steroid Therapy & & \\
Previous mediastinal irradiation & & \\
\hline
\end{tabular}
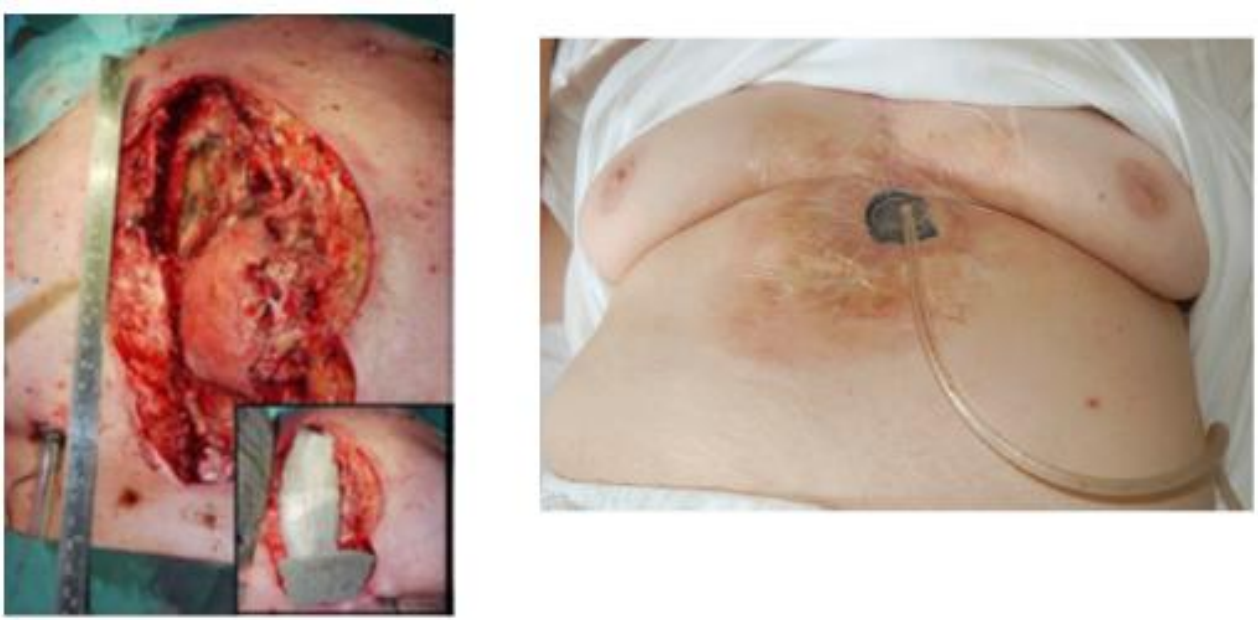

Fig. 1. Sternal Example of vacuum-assisted closure (VAC) therapy application in a sternal wound (Christian et al 2013, De Caridi et al 2014) CDC has been published definition of mediastinitis and osteomielitis

Table 2. US Centers for Disease Control and Prevention definition of mediastinitis and osteomyelitis (Horan et al 2008)

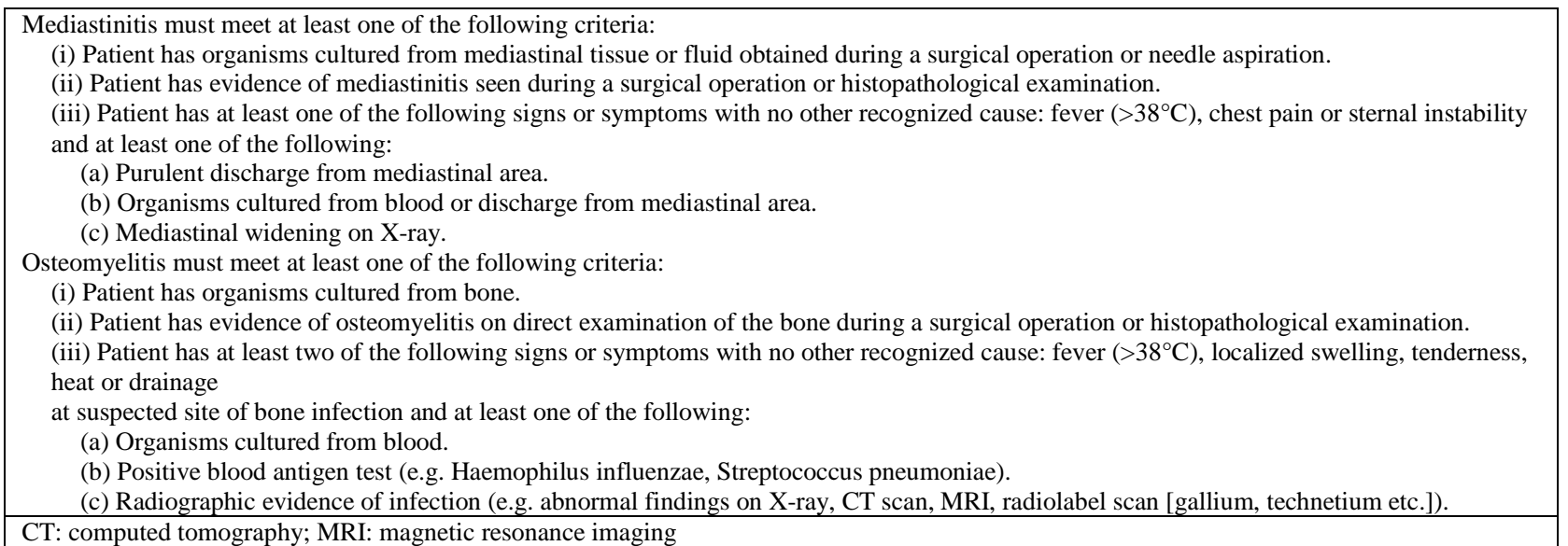




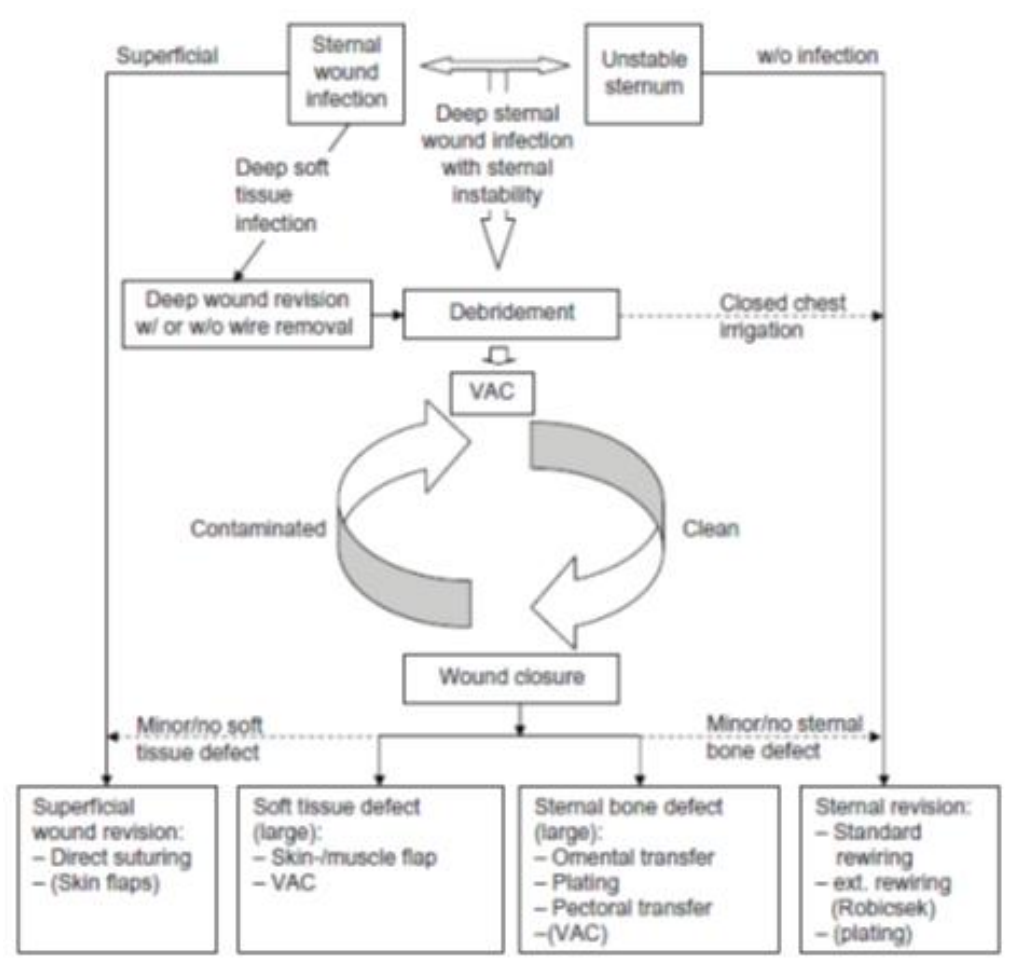

Fig. 2. Treatment algorithm (Leopold \& Christof 2013)

Currently, the European and American cardiothoracic societies provide no guidelines for the treatment of deep sternal wound complications. Patients are treated in many different ways according to general surgery rules of infection and institutional experience. General recommendations for clear-cut and extreme conditions are simpler to suggest, whereas borderline or complex wound situations mandate a more individualized decision making (Fig. 3) (Leopold \& Christof 2013).

Microbial swabs of the sternal wound found the majority of pathogens found in both deep and superficial sternal wound complications belonged to the normal skin flora, more often caused by coagulasenegative staphylococci (S. epidermidis) (Richard et al 2010). However, a number of more aggressive agents was also identified (Table 3).

Table 3. Pathogens identified in deep or superficial wound complications (Claudia et al 2013)

\begin{tabular}{cl}
\hline No. & \multicolumn{1}{c}{ Pathogens found in sterna wound infection } \\
\hline 1 & $\begin{array}{l}\text { Coagulase-negative Staphylococci (S. epidermidis, } \\
\text { warneri, capitis, hominis, micrococcus luteus) }\end{array}$ \\
2 & $\begin{array}{l}\text { Enterobacteriaceae (klebsiellae, P. aerogenes, } \\
\text { serratia, E. coli) }\end{array}$ \\
3 & Staphylococcus aureus (MRSA) \\
4 & Enterococcus faecalis \\
5 & Candida species \\
6 & Corynebacterium amycolatum \\
\hline
\end{tabular}

\section{Vacuum-assisted Closure Therapy (VAC therapy)}

VAC therapy is a therapeutic method using a special sponge or gauze dressing with a vacuum device to promote wound healing. Negative pressure (sub atmospheric pressure from $75-150 \mathrm{mmHg}$ ) is applied to the wound through a special sealed dressing in a continuous or intermittent manner. This novel technology was introduced for medical practices since it was introduced by Morykwas et al (1997) which was based on the work of Fleischmann (1995) (Argenta et al 1997, Morykwas et al 1997, Chiummariello et al 2012).

The VAC therapy has a complementary function and the range of its indications includes pressure sores, stasis ulcers, chronic wounds such as diabetic foot ulcers, post traumatic and post operative wounds, infected wounds such as necrotizing fasciitis or sternal wounds, softtissue injuries, bone exposed injuries, abdominal open wounds and for securing a skin graft (Chiummariello et al 2012).

VAC uses medical grade components consist of cell polyurethane ether foam as a dressing (pore size is generally $400-600 \mathrm{~mm}$ ). This foam is cut to fit and closely applied to the selected wounds. An evacuation tube with side ports, which communicate with the reticulated foam, is embedded in it. The aim of the reticulation being that the negative pressure will be 
applied equally to the entire wound bed. An adhesive drape is then applied over the area with an additional 3$5 \mathrm{~cm}$ border of intact skin to provide an intact seal (Lambert et al 2005).

In 1998 Schneider et al. and Blackburn et al. described the use of the vacuum-assisted closure (VAC®) device negative pressure dressing (KCI, San Antonio, TX, USA) for stabilizing skin grafts by immobilizing themself, limiting shear stresses, eliminating fluid collections and decreasing bacterial contamination: it leaded to a graft successful rate greater than 95\% (Morykwas et al 2001).

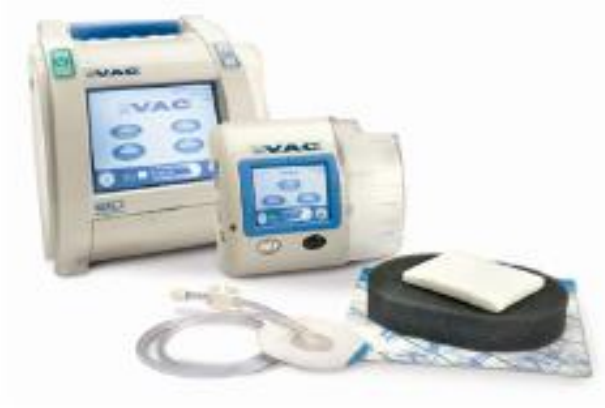

Fig. 4. KCI's proprietary Vacuum Assisted Closure ${ }^{\circledR}$, or V.A.C.® Therapy System (Lambert et al 2005)

In last decade vacuum-assisted closure (VAC) wound therapy system, has gradually gained ground and replaced most of the conventional types of wound treatment due to the faster wound healing, lower length of hospital stay and the subsequent lower in-hospital cost. Moreover, early studies showed that VAC therapy has the potential to reduce both in-hospital and longterm mortality (Matthew et al 2013).

The scientific understanding of the mechanisms of action of negative pressure wound treatment (NPWT) on open wound has grown steadily, some mechanisms are: Wound drainage: reduction of exudate, increased tissue perfusion the peristernal soft and muscular tissue (maximal efficacy between -75 and $100 \mathrm{mmHg}$ ), traction and superficial hypoperfusion induced by negative-pressure stimulate sprouting angiogenesis (via vascular endothelial growth factor gradient) and that cell stretching leads to differentiation (via transforming growth factor- $\beta 1$ expression) of myofribroblasts, known to positively increase neovascularization, extracellular matrix deposition and wound contraction; reduce lateral tension and bring the wound edges together, promoted granulation tissue formation by increasing wound fluid partial pressure of oxygen and lactate levels; reduction of edema; reduce in hematoma and seroma; increasing the delivery of nutritive substances and assisting with the removal of purulent and non-viable material reduce bioburden (Karlakki et al 2013); and reduce bacterial biofilm production (invitro) (MV S 2012, Vincenzo et al 2014).

Although VAC therapy known have many benefits, some complications found like bleeding from a venous bypass graft during dressing changes, right ventricular rupture, painful, toxic shock syndrome, fluid depletion (Lambert et al 2005, Rainer et al 2010). The use of a wound dressing, such as paraffin gauze, in order to protect the RV from direct contact with the polyurethane foam has been recommended (Johan et al 2011).

Considering the VAC and traditional dressings in terms of cost, one might suppose a greater cost for treatment would be attached to the VAC. A certain cost is attached to the purchase or hire of a VAC unit but a published analysis reported that overall, cost of VAC treatment is lower (Lambert et al 2005). Shorter treatment times and fewer additional interventions helping to reduce the cost. Philbeck Jr et al. reviewed the case notes of 1032 patients with chronic wounds treated in the community with the VAC after failing to respond to conventional dressings. They reviewed the time taken to heal as well as analysed costs. The results were compared with published reports of costs of treating same types of wounds with conventional dressings. The average wound in the VAC treated patients took 97 days and $\$ 14,546$ to heal. The average wound of the same type treated conventionally took 247 days and \$23,465 to heal (Philbeck et al 1999).

\section{Modified VAC Therapy Systems}

However, the VAC Therapy system has its disadvantages. It is expensive and requires extensive amounts of product and machinery, as well as functioning suction, and a power source at all times. In addition, the VAC Therapy system requires a trained and vigilant nursing staff. To overcome those problems, the idea to invent a modi!cation of VAC system with simple, accessible, save, massively produced and cheap materials took place. The modification aimed to reach the same benefits as the original one. In some countries the VAC systems modification were conducted by using accessible materials in each country as well using the device for different kinds of wound. The use of this simplest modified VAC (smVAC) has been proved as effective as original one (Danu \& Rosadi 2012). 

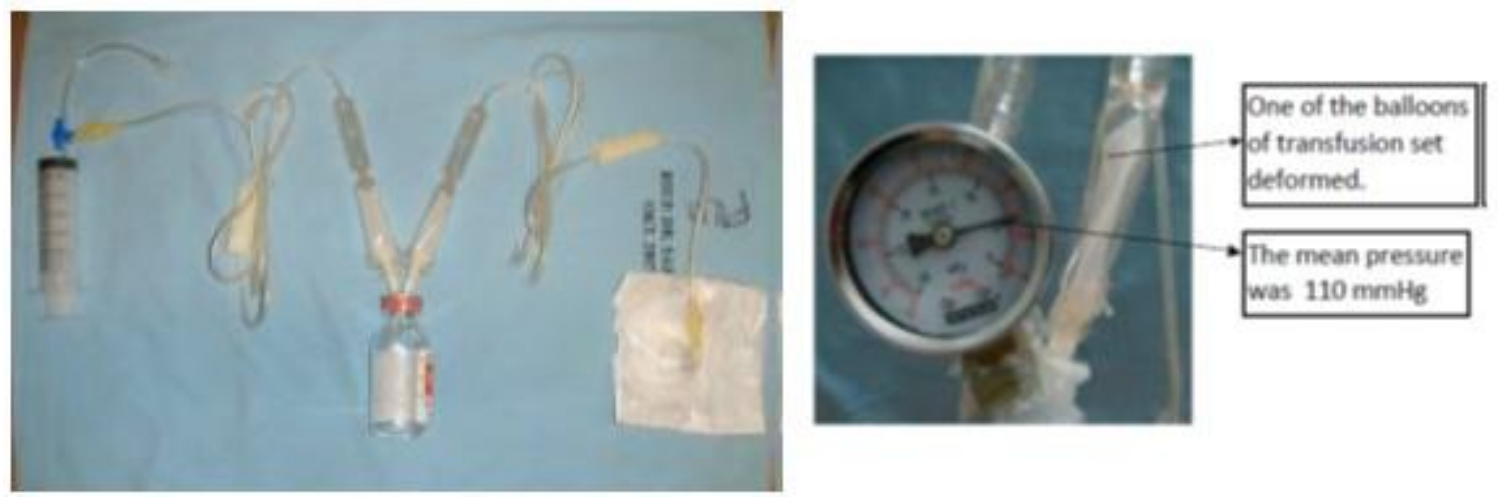

Fig. 5. The simplest vacuum assisted closure (smVAC) (Danu \& Rosadi 2012)

Table 4. Specification of smVAC (Danu \& Rosadi 2012)

\begin{tabular}{|c|c|c|}
\hline Specification & & Alternative \\
\hline Negative Pressure Supply Unit & Canister & $\begin{array}{l}\text { Disposable Syringe } 50 \mathrm{ml} \text { with three way infusion set } 100 \mathrm{cc} \text { closed rubber- } \\
\text { sealed vacuum bottle }\end{array}$ \\
\hline \multirow[t]{4}{*}{ Disposable unit } & Dressing & Sterile gauge \\
\hline & & Grass tulle \\
\hline & & Transparant Adhesive-Occlusive Dressing(tegaderm $($ ), opsite () \\
\hline & Tubing & Otsuka blood transfusion set (elastic ball type) \\
\hline
\end{tabular}

\section{CONCLUSION}

VAC therapy is a safe and cost-effective method of treating complex sternal and thoracic wounds in patients undergoing cardiothoracic surgery. VAC therapy promotes faster wound healing, with shorter hospital stay and subsequent lower in-hospital cost, reducing the mortality rate in the long term. The benefits of modified $\mathrm{VAC}$ is that it is cheaper and can be constructed using simple clinical devices. This device can be used as an alternative device.

\section{REFERENCES}

Argenta LC, Morykwas MJ. Vacuum-asisted closure: a new method for wound control and treatment: clinical experience. Ann Plast Surg. 1997; 38(563-76).

Bovill E, Banwell PE, Teot L, Eriksson E, Song C, et al. Topical negative pressure wound therapy: a review of its role and guidelines for its use in the management of acute wounds. Int Wound J. 2008 ; 5(511-529).

Christian Weinand, Truong Quang Vu Phan, Walter Perbix, W. Xu, Maximilian Jochen Zinser, Stefan Ehrendorfer, Rolf Lefering, et al. A reconstructive algorithm for deep sternal wound coverage: The Cologne-Merheim approach. European journal of plastic surgery. 2013 February; 36(95-104).

Claudia Heilmanna, Rahel Stahla, Christian Schneiderb, Tetyana Sukhodolyaa, Matthias Siepea, Manfred
Olschewskid, Friedhelm Beyersdorfa. Wound complications after median sternotomy: a singlecentre study. Interactive CardioVascular and Thoracic Surgery. 2103;(1-6).

Danu Mahandaru, Rosadi Seswandhana. The simplest modified vacuum assisted closure to treat chronic wound: serial case report. Jurnal Plastik Rekonstruksi. 2012 March;(117-122).

De Caridi Giovanni, Raffaele Serra, Mario Barone, Francesco Monaco. VAC therapy for the treatment of complex wounds after cardio-thoracic surgery. International Wound Journal. 2014 September;(1-4).

Fleck T, Gustafsson R, Harding K, Ingemansson R, Lirtzman MD, et al. The management of deep sternal wound infections using vacuum assisted closure (V.A.C.) therapy. Int Wound J. 2006; 3(273-280).

Horan TC, Andrus M, Dudeck MA. CDC/NHSN surveillance definition of health care-associated infection and criteria for specific types of infections in the acute care setting. Am J Infect Control. 2008; 36(309-32).

Johan Sjo"gren, Ronny Gustafsson, Johan Nilsson, Sandra Lindstedt, Shahab Nozohoor, Richard Ingemansso. Negative-pressure wound therapy following cardiac surgery: bleeding complications and 30-day mortality in 176 patients with deep sterna wound infection. Interactive CardioVascular and Thoracic Surgery. $2011 ; 12(117-120)$. 
K.V. Lambert, P. Hayes, M. McCarthy. Vacuum assisted closure: a review of development and current applications. Eur J Vasc Endovasc Surg. 2005; 29(219-226).

Leopold Rupprecht and Christof Schmid. Deep Sternal Wound Complications: An Overview of Old and New Therapeutic Options. Open Journal of Cardiovascular Surgery. 2013; 6(9-19).

Matthew E. Falagas, Giannoula S. Tansarli, Anastasios Kapaskelis, Konstantinos Z. Vardakas. Impact of Vacuum-Assisted Closure (VAC) Therapy on Clinical Outcomes of Patients with Sternal Wound Infections: A Meta-Analysis of Non-Randomized Studies. PLoS ONE. 2013 May; 8(5).

Michael Gorlitzera, Florian Wagnerb, Steffen Pfeifferc, Sandra Folkmanna, Johann Meinhartd. Institutional report - Cardiac general: A prospective randomized multicenter trial shows improvement of sternum related complications in cardiac surgery with the post thorax vest. Interactive CardioVascular and Thoracic Surgery. 2010; 10(714-18).

Morykwas MJ, Argenta LC, Shelton-Brown El, et al. Vacuum-asisted closure: a new method for wound control and treatment: animal studies and basic foundation. Ann Plast Surg. 1997; 38(553-62).

Morykwas MJ, Faler BJ, Pearce DJ, Argenta LC. Effects of varying levels of subatmospheric pressure on the rate of granulation tissue formation in experimental wounds in swine. Ann Plast Surg. 2001; 47(547).

MV S. Negative pressure therapy: theory and practice. Diabetes Metab Res. 2012; Suppl 1(72-7).

Philbeck TE et al. The clinical and cost effectiveness of externally applied negative pressure wound therapy in the treatment of wounds in home healthcare medicare patients. Ostomy Wound Manag. 1999; 45(11)(41$50)$.
Rainer Petzina, Malin Malmsjo, Christof Stamm, Roland Hetzer. Major complications during negative pressure wound therapy in poststernotomy mediastinitis after cardiac surgery. $\mathbf{J}$ Thorac Cardiovasc Surg. 2010; 140(1133-36).

Richard Baillot, Daniel Cloutier, Livia Montalin, Louise Co^te', Francois Lellouche, Chanel Houde, Genevie`ve Gaudreau, Pierre Voisine. Impact of deep sternal wound infection management with vacuumassisted closure therapy followed by sternal osteosynthesis: a 15-year review of 23.499 sternotomies. European Journal of Cardio-thoracic Surgery. 2010; 37(880-887).

Roemer J. Vosa, Alaaddin Yilmaza, Uday Sonkera, Johannes C. Kelderb and Geoffrey T.L. Kloppenburg. Vacuum-assisted closure of post-sternotomy mediastinitis as compared to open packing. Interactive CardioVascular and Thoracic Surgery. 2011;(1-4).

S. Chiummariello, G. Guarro, A. Pica, C. Alfano. Evaluation of negative pressure vacuum-assisted system in acute and chronic wounds closure. Our experience. G Chir. 2012 October; Vol. 33(358-362).

S. Karlakki, M. Brem, S. Giannini, V. Khanduja, J. Stannard, R. Martin. Negative pressure wound therapy for management of the surgical incision in orthopaedic surgery. A Review of Evidence and Mechanisms for an Emerging Indication. Bone Joint Res. 2013; 2(27684).

Singh K, Anderson E, Harper JG.. Overview and management of sternal wound infection. Semin Plast Surg. 2011; 25(25-33).

Vincenzo Tarziaa, Massimiliano Carrozzinia, Giacomo Bortolussia, Edward Burattoa, Jonida Bejkoa et al. Impact of vacuum-assisted closure therapy on outcomes of sternal wound dehiscence. Interactive CardioVascular and Thoracic Surgery. 2014;(1-6). 